\title{
English as a Foreign Language (EFL) Students' Ability in Identifying Moral Values within Narrative Texts
}

\author{
Widia Yunita and Patriadi Patriadi \\ STAI Hubbulwathan Duri \\ widiayunita@staihubbulwathan.id
}

\author{
ARTICLE HISTORY \\ Received : 24 August 2019 \\ Revised : 9 September 2019 \\ Accepted : 8 October 2019 \\ KEYWORDS \\ English as a Foreign Language \\ (EFL) \\ Reading Comprehension \\ Narrative Text \\ Moral Values
}

\begin{abstract}
The aimed of the research is to find out the students' ability in identifying moral values of narrative text. The research design of this research is descpritive quantitative. The researcher analysed the data from students' test and on the data analysis, the researcher has got result from the students' test, there are: The students who received excellent level is 0 $(0 \%)$, very good level is $29(60 \%)$, good $13(28 \%)$ and 6 come into fair level (12\%), while 0 students got poor level $(0 \%)$. The means score of the students' test is 77 , it means that the students' ability in identifying moral values of narrative text is Good.
\end{abstract}

\section{Introduction}

English is an important subject in Senior High School (SMA) in Indonesia. English is included in Indonesia's National Exams. While some foreign languages are actually taught in optional classes, at the high school level, English is compulsory (Rahman, 2018). It indicates the importance of English in SMA. English as a subject matter in school with the four basic language skills, they are reading, speaking, writing and listening. From these four skills, reading has on the portion in teaching learning process (Molinsky, 2014). Based on the opinion above one of basic skill that should be mastered in English by the student is reading (Budiarti et al., 2019).

The goal of English learning is to equip students with a necessary skill in listening, speaking, reading and writing to communicate (Susilo, 2019). One of subject in English of reading is a reading text. Based on the curriculum of the Eleventh Grade of Senior High School there are some texts that should be learned by the students those are, descriptive text, recount text, and narrative text. The students of Senior High School should be able to comprehend and interpret English reading narrative texts.

The text has an important place in language education and probably they are the most important means of education. The student in Senior High School mostly read narrative texts like short stories, poems and fictional books (Sallabas et al, 2013). The moral value of the text is one of the very important things in which the readers need to concern about. Moral value is one of the generic structures of narrative text in English lesson. In this research, the students are ordered to identify the structure of a text, especially in narrative text. It means that moral value plays an important role in reading comprehension of a narrative text. There is a reason why the moral value is important in reading comprehension of a text especially in narrative. It is because the moral value is the good message that can be taken by the reader or students after they read the narrative text.

In preliminary research when the researcher practiced of field (PPL) as teacher, the researcher was doing informal observation in SMA Negeri 6 Mandau and found some problems about teaching and learning process, especially in narrative text. Firstly, the teacher doesn't use interest media in teaching about narrative, so many students feel bored in learning process. Second, learning process no apparent variation in teaching of narrative. English teacher just give instruction to students to read book or read text and translate it, so some of students not understanding about the text.

Some of the students got difficulties to understand the generic structure of narrative text. When they got reading materials, they need more time to understand the narrative text. They feel bored when they have the reading materials even though the teacher has already tried to give them interesting materials for them. They feel lazy to have the reading materials. When the teacher asked them to do the reading exercises not all the students do it by themselves. Most of them just copied from another friend. They do not care whether the answer is right or not. The point is that they have fulfilled their task without understanding at all.

Some students cannot retell what the narrative text, because many students did not know the narrative. Example when the students read a narrative text, they are only read without knowing the reading about it. All comprehension in reading a narrative text is concentrated on two important things that are the moral value and main idea. The moral 
value of the text is one of the important things in which the readers need to concern about. Moral value is one of the generic structures of narrative text. Character education is an important dimension of children's education because it provides children with different social and ethical lessons (Sallabas et al, 2013). It means that moral value plays an important role in reading comprehension of a narrative text. There is a reason why the moral value is important in reading comprehension of a text. Reading also have a religious practice or moral (Pang, 2013). Moral value of narrative text is one of the points that is being expressed by the researcher to the reader.

Based on the phenomena above, the researcher found some problem as follow:

a) The students have low motivation in English learning especially in narrative text.

b) Some of students cannot understand the meaning of reading text.

c) Some of students got the problem and difficulties to comprehend of generic structures of narrative, especially to identifying and finding moral values of narrative text.

d) Some of student difficulties with their vocabulary and the students' ability in finding moral value still low because they are confused to determine the moral value from the narrative text.

Regarding with the problem or phenomena above, the researchers want to find out more how is students' ability in identifying moral values of narrative text. Based on the phenomena above the researcher is interested to research and discuss about the students' ability in identifying moral values of narrative text at SMA Negeri 6 Mandau. The researcher, therefore want to carry out a research entitle: "The Students' Ability in Identifying Moral Values of Narrative Text at the Eleventh Grade of SMA Negeri 6 Mandau".

\section{Literature Review}

The researcher conducted this study based on some relevant research. One of research entitled "an analysis of students' difficulties in finding the moral value of narrative text at the first semester of the eighth grade in2017/2018 academic year" by Dariyanti, 2017. The researcher found that the students still had difficulties in finding moral value, problem and difficulties with previous knowledge. Therefore, objective of this research is to identify the factors that cause students difficulties in finding moral value of narrative text. The method used in this research was descriptive qualitative. The factors that causes students difficulties in finding moral value were exception in the decoding process, previous knowledge, motivation or perseverance, high level cognitive skills. Based on the result of questionnaire, it can be concluded, that most students were fluent in reading narrative texts in English because they often read narrative text. So, they can read the text in English easily. And then, most of students had problem in their previous knowledge, so they felt difficult to determine the moral value. The difference between this research and researcher's research, there are: this relevant research using qualitative method with technique of collecting data was by analyzing documentation and giving questionnaire to the students. The questionnaire was done to know the factors that causes students' difficulties in finding moral value of narrative text, while the researcher's research use quantitative method with collecting data by using test only to measure students' ability in identifying moral value of narrative text.

Another research is" by Dini Utami Mulyaningsih, 2013 from English Education Study Program of Indonesia University of Education. This research is case study about students' ability in writing narrative texts. The data of this study were nine junior high school students' narrative texts that came from low, middle, and high levels of achievement. The analysis of the data indicated that the students from low and middle achievers have insufficient knowledge of writing narrative. The findings of this study indicate that all students from all levels of achievement have been aware of the obligatory constituent structure of a narrative text that includes orientation, complication, and resolution. Furthermore, in terms of the narrative's language features, different student's from different levels of achievement have different ability in applying the features in the story. The conclusion of this research the low achiever student lacksknowledge oflanguage features ofnarratives. The middle achiever has a better understanding and high achiever has agood understanding of language features of narratives. The differences this research with the researchers' research are: this research is case study while researchers' research quantitative (survey research), subject of this research is junior high school while the researchers' research senior high school, and this research focus to students' ability in narrative text while the researchers' research focus to reading and finding moral values only from narrative text.

\section{Method}

\subsection{Research Design}

This research examines the students' ability in identifying moral values of narrative text at SMA Negeri 6 Mandau. The students' ability in identifying moral values of narrative text has been tested by using test. The researcher took descriptive quantitative. It is a method that the use to describe phenomena of a case.

They have questions of who, what, when, where, how much, how many, and how. Quantitative research is essentially with collecting numerical data to explain a particular phenomenon, particular questions seem immediately suited to being answered using quantitative methods. Quantitative research is a study involving the use and analyses of numerical data using statistical techniques with the formula. 
Quantitative research is research design was designed to produce statistically reliable data that tells us how many people do or think something. Quantitative data typically is in numerical form such as averages, percentage, ratios or ranges.

Quantitative research is especially useful when carrying out a large scale needs assessment or baseline survey. It is independent of the researcher and one should get similar results no matter who carries out the research. It can also be used to measure trends (Nayak, 2015). In this research there is one variable, it is the students' ability in identifying moral values of narrative text.

\subsection{Place and Time of the Research}

The research conducted at the eleventh grade of SMA Negeri 06 Mandau, on May 2019 up to August 2019.The location of SMA Negeri 06 Mandau on the Duri-Dumai Street KM. 18 in Sebangar Town, Sub- District Bathin Solapan (Expansion of Mandau Sub-District) Bengkalis Regency.

\subsection{Subject and the Object of the Research}

The subject of this research is the eleventh grade of SMA Negeri 06 Mandau, and the object of is students' ability in identifying moral values of narrative text.

\subsection{Population and Sample}

The population of this research is the eleventh grade of SMA Negeri 06 Mandau. In this case there are eight classes which consisted of XI IPA 1 (29), XI IPA 2 (30), XI IPA 3 (28), XI IPA 4 (29), XI IPS 1 (31), XI IPS 2 (31), XI IPS 3 (31), XI IPS 4 (30). The total number of the population is 239 students. In this research, the researcher will use Purposive Sampling Technique. Purposive sampling is selecting a sample on the basis of researcher's own knowledge of the population, its elements, and the nature of aims of the research.

That is, the population is non-randomly selected based on a particular characteristic (Nayak and Singh, 2015). Purposive Sampling Technique is a technique which is done because of some causes, such as the researcher has particular purpose toward the sample and the very limited time and funding. So, the sample of this research chooses by six students with the highest scores each class based on test in preliminary research about narrative text, so there are 48 students can be as sample of this research. The researcher just taken six students with the high score because very limited time and funding. So, student that have high score from the first until the sixth was taken be sample from 239 populations or 239 students at the eleventh grade of Senior High School (SMA) Negeri 06 Mandau, Bengkalis Recency, Riau Province. We can see based on the table below:
Table 1. Population Research

\begin{tabular}{cccc}
\hline No & Class & Population & Sample \\
\hline 1 & XI IPA 1 & 29 Students & 6 Students \\
2 & XI IPA 2 & 30 Students & 6 Students \\
3 & XI IPA 3 & 28 Students & 6 Students \\
4 & XI IPA 4 & 29 Students & 6 Students \\
5 & XI IPS 1 & 31 Students & 6 Students \\
6 & XI IPS 2 & 31 Students & 6 Students \\
7 & XI IPS 3 & 31 Students & 6 Students \\
8 & XI IPS 4 & 30 Students & 6 Students \\
& Total & 239 Students & 48 students \\
\hline
\end{tabular}

In order to get some data, which are needed to support this research, the researcher uses description method. The technique as follow:

a) The researcher prepare test about narrative text. The test consist of 20 item of multiple choice which consisted of four options. The reason why the researcher made the test in the form of multiple choice was that is easy to check or to score.

b) The time of this test is 48 minutes. Based on BNSP 60 Examination Question for English in Senior High School all the time alocation is 120 Minutes. It means each question takes 2,4 Minutes. So, if 20 question takes 48 Minutes (BNSP, 2017).

c) Give the test to sample and sample answer the questions from test with the instruction to find or identifying moral values form story about narrative text.

d) Analyze the collection data

e) Prepare the report data

Example of Test:

\section{Farmer and Bird}

A farmer came across a bird with a broken wing. He picked it up, took it home and looked after it lovingly, even though his wife complained bitterly about his wasting too much time on the creature.

After some time, the wing mended and, because the bird did not want the farmer to have kept on arguing with his wife all the time, it decided to go back to its nest.

When the farmer discovered that the bird was gone, he was so upset that he went out to look for it. Eventually, he found it again, and was greeted happily by the whole family of the bird. As a sign of their thanks for his care and attention, the birds gave him a little box, and told him not to open it until he got home.

To his surprise, the farmer found the box full of precious stones. When his wife saw them, she decided that she too deserved a reward, and she went to see the birds. The birds 
gave her a little casket; but this one was full of devils. The devils jumped on her as soon as she opened the casket and chased her away.

Left alone, the farmer went to live near his friend, the bird. There he built a hut of perfumed wood; and the birds decorated it with flowers of every kind.

1. What do we learn from the text?

a. A gift shows kindness.

b. Sufferings bring happiness.

c. Arguing makes you distressed

d. A good deed deserves a reward

\subsection{Technique of Data Analysis}

After distributing the test to the samples, the researcher scored the test by using the following formula :

$$
M=\frac{(X)}{(n)} \times 100
$$

Where: $\mathrm{M}=$ Individual Score

$$
\begin{aligned}
& X=\text { The number of correct answer } \\
& n=\text { The number of item test }
\end{aligned}
$$

To know percentage of students' mastery in answering the test, the researcher using formula:

$P=\frac{f}{N} \times 100$

$$
\text { Where: } \begin{aligned}
\mathrm{P} & =\text { Percentage } \\
\mathrm{F} & =\text { Frequency } \\
\mathrm{N} & =\text { Number of Students }
\end{aligned}
$$

(Sibel Toksoz, 2017)

The students' score will classification into level on the table below:

\begin{tabular}{cc}
\hline The Score Mastery & Category \\
\hline Excellent & $90-99$ \\
Very Good & $80-89$ \\
Good & $70-79$ \\
Fair & $60-69$ \\
Poor & $\leq 60$ \\
\hline
\end{tabular}

Table 2. The classify of students' score

The important statistical measures that are used to summarize the research data are measures of central tendency, they are:

a) Mean: the mean of average is probably the most commonly used method of describing central tendency. To know average score of students' ability in applying the quantifiers, the researcher uses formula:

$$
\mu=\frac{\sum x}{N}
$$

$\Sigma x \quad=$ The summation of individual score

$\mu \quad=$ The mean of score

$\mathrm{N} \quad=$ The total number of respondent

b) Median: the mean of median is the middle value that separates the higher half from the lower half of the data set. The median and the mode are the only measures of central tendency that can be used for ordinal data in research, in which values are ranked relative to each other but are not measured absolutely.

c) Mode: the mean of mode is the most frequent value in the data set. This is the only central tendency measure that can be used with nominal data in research, which have purely qualitative category assignments.

Besides central tendency, measure of dispersion also the important statistical to summarizes the research data statistic. Measures of dispersion are descriptive statistics that describe how similar a set of scores are to each other one of them is the Range : the mean of the range as the difference between the largest score in the set of data and the smallest score in the set of data.

$$
\mathrm{X}_{\mathrm{L}}-\mathrm{X}_{\mathrm{S}}
$$

What is the range of the following data:

$$
\begin{array}{llllllllll}
4 & 8 & 1 & 6 & 6 & 2 & 9 & 3 & 6 & 9
\end{array}
$$

The largest score $\left(\mathrm{X}_{\mathrm{L}}\right)$ is 9 ; the smallest score $\left(\mathrm{X}_{\mathrm{S}}\right)$ is 1 ; the range is $X_{L}-X_{S}=9-1=8$

\section{Results}

\subsection{The Data Presentation}

After the researcher conducted test on 48 samples by providing test which is consisted of 20 item of multiple choice about narrative text based on short story in narrative text, such as story about "farmer and Bird, the lion and the mouse, the magic box and others story of narrative text. In this chapter, the researcher explains the description of the data and present the result of the test given to the eleventh grade students of Senior High School (SMA)Negeri06 Mandau. The presented data were obtained through test that the test data is taken from the score of students.

Before give to sample that 48 respondents, the researcher was given preliminary research test to population. The researcher done it to found sample in this research and the researcher was explained about technique to found sample in chapter III. Based on the preliminary research test, researcher found students' score in English generally about narrative, not specific about moral value of narrative text. The researcher was taken 48 students from each class as sample. We can see six students each class with the higher score: 
Table 3. Students' score in preliminary research

\begin{tabular}{|c|c|c|c|}
\hline Students & Correct Answer & Score & Class \\
\hline Student 1 & 13 & 65 & \multirow{6}{*}{ IPA 1} \\
\hline Student 2 & 13 & 65 & \\
\hline Student 3 & 12 & 60 & \\
\hline Student 4 & 12 & 60 & \\
\hline Student 5 & 12 & 60 & \\
\hline Student 6 & 12 & 60 & \\
\hline Student 1 & 14 & 70 & \multirow{6}{*}{ IPA 2} \\
\hline Student 2 & 14 & 70 & \\
\hline Student 3 & 14 & 70 & \\
\hline Student 4 & 14 & 70 & \\
\hline Student 5 & 13 & 65 & \\
\hline Student 6 & 12 & 60 & \\
\hline Student 1 & 15 & 75 & \multirow{6}{*}{ IPA 3} \\
\hline Student 2 & 14 & 70 & \\
\hline Student 3 & 14 & 70 & \\
\hline Student 4 & 14 & 70 & \\
\hline Student 5 & 13 & 65 & \\
\hline Student 6 & 13 & 65 & \\
\hline Student 1 & 14 & 70 & \multirow{6}{*}{ IPA 4} \\
\hline Student 2 & 14 & 70 & \\
\hline Student 3 & 13 & 65 & \\
\hline Student 4 & 13 & 65 & \\
\hline Student 5 & 13 & 65 & \\
\hline Student 6 & 13 & 65 & \\
\hline Student 1 & 14 & 70 & \multirow{6}{*}{ IPS 1} \\
\hline Student 2 & 14 & 70 & \\
\hline Student 3 & 14 & 70 & \\
\hline Student 4 & 14 & 70 & \\
\hline Student 5 & 14 & 70 & \\
\hline Student 6 & 13 & 65 & \\
\hline Student 1 & 14 & 70 & \multirow{6}{*}{ IPS 2} \\
\hline Student 2 & 14 & 70 & \\
\hline Student 3 & 14 & 70 & \\
\hline Student 4 & 13 & 65 & \\
\hline Student 5 & 13 & 65 & \\
\hline Student 6 & 13 & 65 & \\
\hline Student 1 & 13 & 65 & \multirow{6}{*}{ IPS 3} \\
\hline Student 2 & 13 & 65 & \\
\hline Student 3 & 13 & 65 & \\
\hline Student 4 & 13 & 65 & \\
\hline Student 5 & 13 & 65 & \\
\hline Student 6 & 12 & 60 & \\
\hline Student 1 & 12 & 60 & \multirow{6}{*}{ IPS 4} \\
\hline Student 2 & 12 & 60 & \\
\hline Student 3 & 12 & 60 & \\
\hline Student 4 & 12 & 60 & \\
\hline Student 5 & 12 & 60 & \\
\hline Student 6 & 12 & 60 & \\
\hline
\end{tabular}


Table 4. The Students' Scores, Correct Answer, and Classification in Test

\begin{tabular}{|c|c|c|c|}
\hline Students & Correct Answer & Score & Classification \\
\hline 1 & 14 & 70 & Good \\
\hline 2 & 15 & 75 & Good \\
\hline 3 & 16 & 80 & Very Good \\
\hline 4 & 17 & 85 & Very Good \\
\hline 5 & 17 & 85 & Very Good \\
\hline 6 & 14 & 70 & Good \\
\hline 7 & 16 & 80 & Very Good \\
\hline 8 & 15 & 75 & Good \\
\hline 9 & 16 & 80 & Very Good \\
\hline 10 & 17 & 85 & Very Good \\
\hline 11 & 16 & 80 & Very Good \\
\hline 12 & 17 & 85 & Very Good \\
\hline 13 & 17 & 85 & Very Good \\
\hline 14 & 17 & 85 & Very Good \\
\hline 15 & 16 & 80 & Very Good \\
\hline 16 & 16 & 80 & Very Good \\
\hline 17 & 13 & 65 & Fair \\
\hline 18 & 14 & 70 & Good \\
\hline 19 & 16 & 80 & Very Good \\
\hline 20 & 16 & 80 & Very Good \\
\hline 21 & 17 & 85 & Very Good \\
\hline 22 & 16 & 80 & Very Good \\
\hline 23 & 17 & 85 & Very Good \\
\hline 24 & 15 & 75 & Good \\
\hline 25 & 17 & 85 & Very Good \\
\hline 26 & 13 & 65 & Fair \\
\hline 27 & 17 & 85 & Very Good \\
\hline 28 & 16 & 80 & Very Good \\
\hline 29 & 14 & 70 & Good \\
\hline 30 & 15 & 75 & Good \\
\hline 31 & 16 & 80 & Very Good \\
\hline 32 & 16 & 80 & Very Good \\
\hline 33 & 16 & 80 & Very Good \\
\hline 34 & 14 & 70 & Good \\
\hline 35 & 13 & 65 & Fair \\
\hline 36 & 12 & 60 & Fair \\
\hline 37 & 16 & 80 & Very Good \\
\hline 38 & 13 & 65 & Fair \\
\hline 39 & 15 & 75 & Good \\
\hline 40 & 16 & 80 & Very Good \\
\hline 41 & 15 & 75 & Good \\
\hline 42 & 17 & 85 & Very Good \\
\hline 43 & 16 & 80 & Very Good \\
\hline 44 & 15 & 75 & Good \\
\hline 45 & 17 & 85 & Very Good \\
\hline 46 & 16 & 80 & Very Good \\
\hline 47 & 12 & 60 & Fair \\
\hline 48 & 15 & 75 & Good \\
\hline Total & & 3710 & \\
\hline
\end{tabular}


Table 5. The Percentage of Students' Score

\begin{tabular}{cccc}
\hline No & Category & Frequency & Percentage \\
\hline 1 & Excellent & 0 & $0 \%$ \\
2 & Very Good & 29 & $60 \%$ \\
3 & Good & 13 & $28 \%$ \\
4 & Fair & 6 & $12 \%$ \\
5 & Poor & 0 & $00 \%$ \\
& Total & 48 & $100 \%$ \\
\hline
\end{tabular}

To know the percentage of students' score on the table above the researcher using formula as follow:

$$
\mathrm{P}=\frac{f}{N} \mathrm{X} 100
$$

Where: $\mathrm{P}=$ Percentage

$$
\mathrm{F}=\text { Frequency }
$$$$
\mathrm{N}=\text { Number of Students }
$$

The data above shown students' ability in answering the test items. Based on the data above we can seen if the students has a different score as a theirs ability.

$$
\text { The students' ability in identifying moral values of narrative text at SMA Negeri }
$$

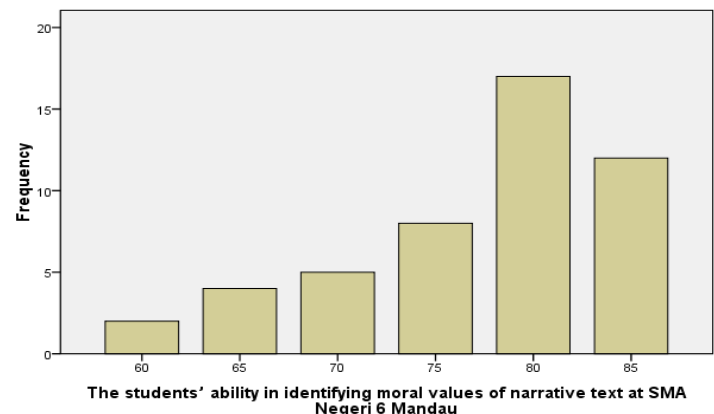

Figure 1. The students' ability in identifying moral values of narrative text at SMA Negeri 6 Mandau

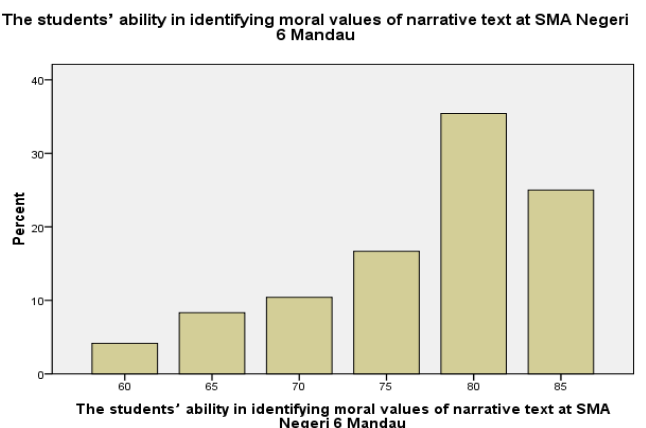

Figure 2. The students' ability in identifying moral values of narrative text at SMA Negeri 6 Mandau

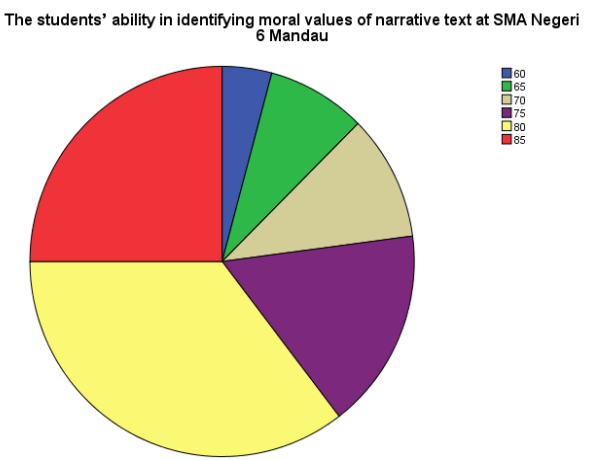

Figure 3. Frequencies

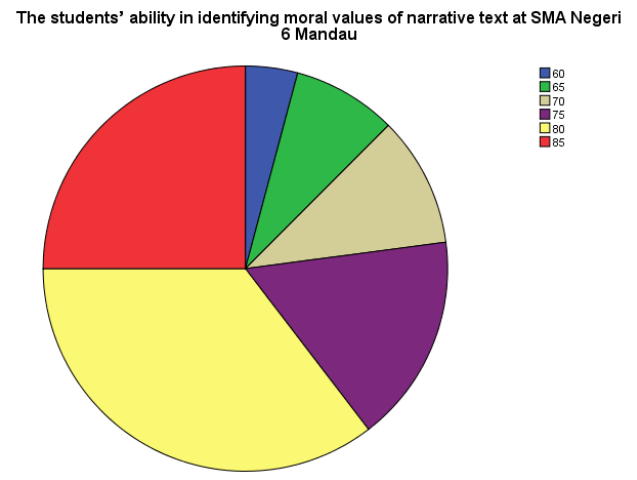

Figure 3. Percentage

\subsection{The Data Analysis}

In this chapter, the researcher has presented the data gotten from the research. To continue, the researcher presents the statistical result followed by discussion about the students' ability in answering the test item about moral value of narrative text. To know thestudents' ability in identifying moral values of narrative text at SMA Negeri 6 Mandau, the researcher administrated the test. The test consists of 20 items, the number of students or respondent was 48 respondents. 
On the data analysis researcher uses the formula of statistical to get the mean (M) and standard deviation (SD). The result of score mean of each test given is calculated by using formula as above. Moreover, to analyze the data, the researcher would present some result, which the data also has been distributed and analyzed. The result will be stated as follow:

Table 6. Descriptive Statistic of the students' ability in identifying moral values of narrative text at SMA Negeri 6 Mandau.

\begin{tabular}{lcc}
\hline \multirow{2}{*}{$\mathrm{N}$} & Valid & 48 \\
\cline { 2 - 3 } & Missing & 0 \\
\hline Mean & 77.29 \\
Median & 80.00 \\
Mode & 80 \\
Std. Deviation & 7.068 \\
Variance & 49.956 \\
Range & 25 \\
Minimum & 60 \\
Maximum & 85 \\
Sum & 3710 \\
\hline
\end{tabular}

From the data above, we can see the data from the students' ability in identifying moral values of narrative text at SMA Negeri 6 Mandau mean score of students in test was 77 , median 80 , mode 80 , standard deviation 7.068 , variance 49.956 , range 25 , minimum 60 , maximum 85 , and sum of score 3710 .

To find mean of score the researcher using formula as below:

$$
\begin{aligned}
& \mu=\frac{\sum x}{N} \\
& \mu=\frac{3710}{48} \\
& \mu=77
\end{aligned}
$$

\subsection{The Findings}

Based on the formulation of the problem from this research as stated in the chapter I is "how the students' ability in identifying moral values of narrative text at SMA Negeri 6 Mandau?" the researcher has analyzed the data and was got the result of the research. To know how is the students' ability in identifying moral values of narrative text at SMA Negeri 6 Mandau, the researcher was given test to the students that 48 persons at the eleventh grade of SMA Negeri 06 Mandau. Test about narrative text with instruction to identifying or to find moral value of narrative text. So, for clearly we can see from the table of percentage from students as follow:
Table 7. The percentage of the students' ability in reading comprehension of short functional text at the seventh grade of SMP Negeri 05 Mandau

\begin{tabular}{ccccc}
\hline No & Score & Frequency & Percentage & $\begin{array}{c}\text { Ability } \\
\text { Level }\end{array}$ \\
\hline 1 & $90-99$ & 0 & $0 \%$ & Excellent \\
2 & $80-89$ & 29 & $60 \%$ & $\begin{array}{c}\text { Very } \\
\text { Good }\end{array}$ \\
3 & $70-79$ & 13 & $28 \%$ & Good \\
4 & $60-69$ & 6 & $12 \%$ & Fair \\
5 & $\leq 60$ & 0 & $0 \%$ & Poor \\
& Total & $\mathbf{4 8}$ & $100 \%$ & \\
\hline
\end{tabular}

The table above shows the students' score of in answering the test items range are excellent, very good, good, fair and poor. The students who got excellent level is $0(0 \%)$, very good level is $29(60 \%)$, good $13(28 \%)$ and 6 come into fair level $(12 \%)$, while 0 students got poor level $(0 \%)$.

From the table above also can be seen the total number of the sample 48 students' who took the test. The researcher also has analyzed the data, and got the mean score as follow:

$$
\begin{aligned}
& \mu=\frac{\sum x}{N} \\
& \mu=\frac{3710}{48} \\
& \mu=77
\end{aligned}
$$

From the formula above was got the mean score of the test $\mathbf{7 7}$, its' means based on the category in the table of classify of students' score, the category of the students' ability in identifying moral values of narrative text at SMA Negeri 6 Mandau is Good Ability.

\section{Conclusion}

This studies are formulated as "how is the students" ability in identifying moral values of narrative text at SMA Negeri 6 Mandau?". The research design of this research was a descriptive quantitative, the researcher took the total number of sample 48 students and given test of multiple choice. The test consist of 20 item of multiple choice which consisted of four options. The reason why the researcher made the test in the form of multiple choice was that is easy to check or to score. It used to find out the students' ability in identifying moral values of narrative text.Narrative text based on short story in narrative text, such as story about "farmer and Bird, the lion and the mouse, the magic box and others story of narrative text. 
To know the students' ability in identifying moral values of narrative text at SMA Negeri 6 Mandau the researcher analyzed the data from students' test and on the data analysis, the researcher has got result from the students' test, there are: The students who got excellent level is 0 $(0 \%)$, very good level is $29(60 \%)$, good $13(28 \%)$ and 6 come into fair level $(12 \%)$, while 0 students got poor level $(0 \%)$.. The means score of the students' test is 77 , it means that the students' ability in identifying moral values of narrative text at SMA Negeri 6 Mandau is at Good category. The researcher concludes that the students' at Eleventh Grade of SMA Negeri 6 Mandau haven't problem in in identifying moral values of narrative text, but some of students at at Eleventh Grade of SMA Negeri 6 Mandau still have problem in identifying moral values of narrative text.

\section{References}

Allen, L. K., Snow, E. L., Crossley, S. A., Jackson, G. T., \& McNamara, D. S. (2014). Reading comprehension components and their relation to writing. LAnnee psychologique, 114(4), 663-691.

Barker, I. (2009). Life Accents Reading Comprehension Skills. Singapore: Marshall Cavendish.

Basir, M. (2015). Evaluasi Pendidikan. Sulsel: Lempena Intimedia.

Bruno C. (2015). Ethics and Values Educations Manual for Teacher and Educators. Newyork: Erasmus.

Budiarti, V., Syafitri, Y. D. T., \& Derin, T. (2019). An Article Review on "Reading Comprehension Strategy Instruction in a First-Year Course: An Instructor's Self-Study". Elsya : Journal of English Language Studies, 1(1), 16-21. https://doi.org/10.31849/elsya.v1i1.2543

Denise Y., Neilane L., \& Brdiget A. (2013). Reading and Writing general training. Australia: Oxford University Press.

Derin, T., Nursafira, M. S., Yudar, R. S., Gowasa, N. S., \& Hamuddin, B. (2020). Persuasive Communication: What Do Existing Literature Tells Us About Persuasive Communication Among Students?. Utamax: Journal of Ultimate Research and Trends in Education, 2(1), 12-18.

Engelhardt, D. (2013). Practice Makes Perfect Advanced English Reading and Comprehension. McGraw Hill Professional..

Eyyuuml, M. (2013). Analysis of narrative texts in secondary school textbooks in terms of values education. Educational Research and Reviews, 8(8), 361-366.

Molinsky, S. J. (2014). Teaching English as a Foreign Languange. North Amrecican: Alpharetta Georgia.
Mulyaningsih, D. U. (2013). AN ANALYSIS OF STUDENTS'ABILITY IN WRITING NARRATIVE TEXTS: A Case study at One Public Junior High Schools in Bandung (Doctoral dissertation, Universitas Pendidikan Indonesia).

Nayak, J. K., and Singh, P. (2015). Fundamentals of Research Methodology: Problems and Prospects. New Delhi: SSDN publishers and distributors.

Pangm, S. E., Muaka A., Bernard E. S., and Kamil, M. L. (2013). Teaching Reading. Chicago: IAE.

Paterson, H. (2015). Text Type Book. Campbell High School.

Rahman, F. (2018). The Constraints of Foreign Learners in Reading English Literary Works: A Case Study at Hasanuddin University. Journal of Arts and Humanities, 7(2), 01-12.

Rini, J. E. (2014). Running head: THE POSITION OF ENGLISH IN INDONESIA. Surabaya: Petra Christian University Press.

Shea, M. \& Robert, N. (2016). The Five Strategy for Reading Comprehension. United Stated of America: Learning Science Internasional.

Soetjipto \& Kosasi, R. (2013). Profesi Keguruan. Jakarta: Rineka Cipta.

Suharsimi, A. (2013). Dasar-dasar evaluasi pendidikan edisi 2. Jakarta PT Bumi Aksara.

Sumantri, M. (2017). Perkembangan Peserta Didik, Tangerang Selatan: Penerbit Universitas Terbuka.

Susilo, N. (2019). Kahoot apps in ELT context: An alternative learning strategy. ELSYA: Journal of English Language Studies, 1(1), 11-15.

Toksöz, S., \& Ertunç, A. (2017). Item analysis of a multiple-choice Exam. Advances in Language and Literary Studies, 8(6), 141-146. 